\title{
TEMPAT RETRET KOTA
}

\author{
Vincent Tan ${ }^{1)}$, Alvin Hadiwono ${ }^{2)}$
}

1) Program Studi S1 Arsitektur, Fakultas Teknik, Universitas Tarumanagara, Vincent.tan37@yahoo.com

2) Program Studi S1 Arsitektur, Fakultas Teknik, Universitas Tarumanagara, alvinhadiwono@ymail.com

\begin{abstract}
Abstrak
Dunia ini telah menciptakan perubahan besar, hal ini dianggap sebagai dampak dari arus globalisasi yang sudah tidak dapat dibendung lagi. Arus globalisasi ini mengakibatkan stress bagi generasi milennial. Milennial adalah mereka yang terkena dampak arus ini terbesar dengan kelahirannya pada tahun 1981-2000. Mereka juga adalah orang-orang dengan usia produktif. Penelitian dari Mental Health Foundation (MHF, 2018) menemukan generasi milenial lebih stres dibandingkan kelompok usia lain yang lebih tua seperti generasi $X$. Hal ini menarik perhatian akan hal kesehatan mental serta fisik khususnya spiritual untuk menanggulangi ini. Adapun tujuan dari proyek ini yaitu mengenalkan tipe baru tempat spiritualitas pada jaman generasi milennial, membuka pengertian dan pemikiran baru tentang spiritualitas dalam arsitektur, menghasilkan karya arsitektur yang mendukung perubahan baru pada jaman generasi milennial, dan meningkatkan awareness pada generasi sebelum-sesudah millennial akan arahan arsitektur spiritualitas kedepan. Kajian Teori yang mendasari proyek desain ini diambil dari buku Suzan Caroll yang berjudul Seven Steps to Soul dan metode yang digunakan adalah Thematic Narrative Architecture.Pendekatan Thematic Narrative Architecture adalah pendekatan desain dengan menceritakan sebuah proses yang memperhatikan penerapan tema sebagai unsurunsur pada bangunan. Pendekatan ini didukung oleh sub-metode lainnya yaitu Spatial Gestalts, Experiential Archetypes dan Reference. Proyek rancangan ini membawa pengguna kedalam sebuah pengalaman spiritual yang bertujuan untuk menjadi tempat pelepasan diri bagi semua orang khususnya millennial.
\end{abstract}

Kata kunci: arsitektur; milenial; spiritualitas

\begin{abstract}
This world has created major changes, this is considered as the impact of the current globalization that cannot be stopped anymore. This stream of globalization has caused stress for the millennial generation. Millennials are those that are affected by this current, the largest - with their birth in 1981-2000. They are also people of productive age. Research from the Mental Health Foundation (MHF, 2018) found millennials were more stressed than other older age groups such as generation $X$. This attracted attention to mental and physical health, especially spiritual issues to overcome this. The purpose of this project is to introduce a new type of place of spirituality in the millennial generation, to open new understandings and thoughts about spirituality in architecture, to produce architectural works that support new changes in the millennial generation, and to increase awareness in the millennial prepost architectural direction future spirituality. Theoretical study that underlies this design project is taken from Suzan Caroll's book entitled Seven Steps to Soul and the method used is Thematic Narrative Architecture. Thematic Approach Narrative Architecture is a design approach by telling a process that considers the application of themes as elements in a building. This approach is supported by other sub-methods, namely Spatial Gestalts, Experiential Archetypes and Reference. This design project brings users into a spiritual experience that aims to become a place of self-release for all people, especially millennials.
\end{abstract}

Keywords: architecture; millenial; spirituality 


\section{PENDAHULUAN}

Dalam rentang lini-masa kurang lebih 20 tahun terakhir, dunia ini telah menciptakan perubahan besar, hal ini dianggap sebagai dampak dari arus globalisasi yang sudah tidak dapat dibendung lagi. Arus globalisasi ini mengakibatkan stress bagi generasi millennial. Millennial adalah mereka yang terkena dampak arus ini terbesar -dengan kelahirannya pada tahun 19812000. Mereka juga adalah orang-orang dengan usia produktif.

Menurut Badan Kesehatan Dunia (WHO), bahwa 3 per milyar dari sekitar 32 juta penduduk di Jawa Tengah menderita gangguan kejiwaan dan 19 per milyar lainnya menderita stress. Sementara itu, catatan sipil DKI Jakarta menunjukkan jumlah penduduk DKI Jakarta saat ini mencapai 9,5 juta jiwa. Jumlah penduduk yang stress mencapai 1.33 juta (14 persen dari 9,5 juta), sementara stress mencapai 95.000 - 285.000 orang (13 persen dari 9,5 juta) (Hidayat, 2012). Millennial adalah mereka yang terkena dampak arus ini terbesar dengan kelahirannya pada tahun 1981-2000. Serta penelitian dari Mental Health Foundation (MHF, 2018). menemukan generasi milenial lebih stres dibandingkan kelompok usia lain yang lebih tua seperti generasi $X$. Hal ini menarik perhatian akan hal kesehatan mental serta fisik khususnya spiritual untuk menanggulangi ini. Stres yang terjadi selama proses perkembangan dapat mengakibatkan tiga kondisi, yaitu perubahan persepsi diri, perubahan hubungan dengan orang lain, serta perubahan filosofis mengenai prioritas, apresiasi, dan spiritualitas. Penurunan produktivitas dan stres merupakan proses resiprokal (timbal balik yang berkelanjutan) sehingga ketika manusia merasa sangat bergantung pada orang lain, maka ia akan mengalami stres. Spiritualitas membuat individu memiliki kemampuan transenden dalam berespon terhadap peristiwa yang terjadi sepanjang hidupnya. Proses transendensi tersebut terjadi karena individu memiliki keyakinan diri (self-compassion) yang baik sehingga dapat memiliki mekanisme koping yang lebih baik $(p<0,001)$ (Perez-Blasco et al, 2016).

Menurut Heber (1987 dalam Rohman, 2006) hasil riset telah membuktikan bahwa orang yang spiritualitasnya baik, mempunyai kemungkinan melanjutkan kehidupan lebih baik. Bagi yang spiritualistasnya tidak baik, menunjukan tujuan hidup kurang, tidak dicintai, ketidakbebasan dan takut mati. Sementara orang yang spiritualitasnya baik, tidak takut mati, dan lebih menerima kehidupan. Jika mereka cemas terhadap kematian disebabkan cemas pada proses bukan pada kematian itu sendiri. Pemahaman akan bagaimana sebuah proses spiritual dapat dialami dan diterapkan akan menjadi sebuah pengetahuan yang berharga dalam upaya menuju arsitektur yang lebih bermakna. Sebuah pemahaman yang diharapkan mampu menjawab pertanyaan, bagaimana sebuah ruang arsitektur dapat membantu proses perjalanan spiritual seseorang ? Yang akan di terapkan dalam perancangan arsitektur jurnal "Tempat Retret Kota".

\section{Latar Belakang Arsitektur}

Sebagai manusia kita menemukan ketertarikan terhadap sesuatu saat merasakan seolah 'mengenal' sesuatu tersebut, dan merupakan penjelasan logis mengapa kita terbawa emosi saat menonton sebuah film atau mendengar sebuah lagu. "We are lonesome animals. We spend all our life tyring to be less lonesome. One of our ancient methods is to tell a story begging the listener to say-and to feel- 'yes, that's the way it is, or at least that's the way ifeel it'. You're not as alone as you thought" (Steinback, 1930). Jadi dapat dipahami bahwa bercerita adalah kebutuhan alamiah bagi manusia yang menggunakannya untuk menciptakan hubungan dengan manusia lain untuk membuat dirinya sendiri dapat lebih dimengerti.

Cerita atau disebut juga sebagai narasi atau narrative, adalah sesuatu yang tersusun pada media tertentu yang dianggap sesuai untuk menyampaikan suatu nilai yang penting untuk diketahui oleh orang lain. Bercerita atau storytelling adalah salah satu bentuk seni tertua dalam kebudayaan manusia, yang telah ada sepanjang sejarah sejak manusia mulai mengenal bahasa, dan bahkan sebelum itu. Bentuk paling awal dari bercerita adalah secara oral dengan media berupa suara, dibantu dengan gerak tubuh dan ekspresi. Seiring berlalunya peradaban cerita telah digoreskan, dipahat, diukir, dilukis, ditulis, dicetak, dan direkam. Sehingga suatu ide atau 
gagasan yang sebelumnya hidup dari generasi ke generasi hanya dengan mengandalkan ingatan saja, kini memiliki media lain untuk menjaganya.

Arsitek si Pencerita dan tidak hanya Arsitek si Pembangun dapat menjadi suatu hal yang menarik." Storytelling is not typically thought of as the role of architect, but truth be told, the ability to guide and shape one's set of experiences through design is arguably the most impacting of narrative devices" [Maze, 2006]. Sehingga hasil karya yang dihasilkan menjadi lebih relevan dengan manusia dan tidak terasa asing. "I believe that where architecture avoids the nexus between these two realms, built form fails to engage us and alienation ensues " (Van Schaik, 2002). Istilah narrative architecture ini juga telah dipakai untuk menjelaskan upaya menghubungkan words dan spatial experience, dalam upaya mencari suatu bentuk arsitektur yang berorientasi kepada manusia sebagai pengguna ruangnya.

Pemahaman akan bagaimana sebuah ruang dapat dialami seperti mengalami sebuah cerita akan menjadi sebuah pengetahuan yang berharga dalam upaya menuju arsitektur yang lebih bermakna. Sebuah pemahaman yang diharapkan mampu menjawab pertanyaan, bagaimana apresiasi terhadap arsitektur dapat dicapai melalui ruang yang dapat dinikmati layaknya sebuah cerita? Aspek apa saja yang dapat menjadikan sebuah ruang menjadi bercerita? Leon Van Schaik dalam introduction untuk Poetics in Architecture, menyebutkan bahwa narrative architecture adalah upaya yang telah digunakan untuk menyatukan specialist knowledge yang dimiliki oleh para perancang (pencerita) dengan human knowledge yang dimiliki oleh orang-orang yang menggunakan hasil perancangan (orang yang menikmati cerita). Sehingga hasil karya yang dihasilkan menjadi lebih relevan dengan manusia dan tidak terasa asing. "I believe that where architecture avoids the nexus between these two realms, built form fails to engage us and alienation ensues" (Van Schaik, 2002). Istilah narrative architecture ini juga telah dipakai untuk menjelaskan upaya menghubungkan words dan spatial experience, dalam upaya mencari suatu bentuk arsitektur yang berorientasi kepada manusia sebagai pengguna ruangnya.

\section{KAJIAN LITERATUR}

\section{Spirituality For Architecture}

Why spirituality?

Sebagai bentuk pemahaman dan penguasaan tema proyek "The new-modern worship space", perlu untuk memahami dua elemen penting didalamnya yaitu Spiritualitas, Humanisme dan Arsitektur sebagai satu kesatuan mutualis positif. Untuk mengenal nilai spiritualitas pada arsitektur, Maslow's hierarchy of human needs memberikan titik awal yang unik dan mendasar. Lima kebutuhan dasar yang awalnya diidentifikasi Maslow adalah fisiologis, keamanan, cinta, penghargaan, dan aktualisasi diri. Dia menetapkan bahwa kebutuhan-kebutuhan ini bersifat hierarkis dan bahwa ketika seseorang cukup puas, kebutuhan selanjutnya yang lebih tinggi akan muncul (Maslow, 1943). Hampir tiga dekade kemudian, Maslow menetapkan bahwa tingkat motivasi keenam diperlukan, di atas aktualisasi diri, yang dihasilkan dari seorang individu yang memiliki "puncak pengalaman" (Maslow, 1961). Penelitian terbaru ke dalam jurnal Maslow telah mendefinisikan tingkat keenam ini sebagai transendensi-diri, karakteristik individu yang berusaha untuk mencapai tujuan di luar diri yang melibatkan pelayanan kepada orang lain, pengabdian kepada cita-cita (misalnya kebenaran, seni) atau penyebab (misalnya sosial keadilan, lingkungan hidup, pengejaran sains, keyakinan agama) dan keinginan untuk dipersatukan dengan apa yang dianggap sebagai transenden atau ilahi (Rivera, 2006). Hierarki Maslow dan pertimbangannya tentang aktualisasi diri dan transendensi-diri memberikan argumen yang meyakinkan untuk mengejar komitmen 'spiritual' dalam desain. Penyelidikan ke dalam "growing trend of place-breaking" yang disebabkan oleh perubahan iklim dan perselisihan politik / sipil telah membuat orang lain mengatakan bahwa hal itu mungkin terbukti sangat tepat untuk mendalami seputar potensi spiritual untuk diimplementasikan dan menginspirasi perencanaan kota, desain arsitektur, pembuatan tempat, dan pembuatan ruang (Sinclair, 2011). Di dunia modern tempat-tempat yang kita huni, baik itu pribadi atau umum, adalah wadah 
kebutuhan kita sebagai manusia dipelihara dan dipuaskan. Cukup mudah untuk melihat bagaimana kota dapat memenuhi kebutuhan fisiologis dan keselamatan, dan memperhatian lebih besar terhadap sosial kota kehidupan, seperti Jane Jacobs, yang berdebat untuk memenuhi kebutuhan kota dengan cinta dan harga diri. Cara-cara di mana lingkungan yang dibangun merespon kebutuhan aktualisasi diri dan transendensi-diri menjadi lebih sulit untuk diidentifikasi, dioperasionalkan, dan diatasi. Subyektivitas yang melekat dan sifat spiritualitas yang muskil, khususnya dalam konteks desain modern mengarah ke diskusi yang menantang dan kontroversial, tetapi justru kualitas dan tantangan inilah yang menurut penulis membuat diskusi bermanfaat.

\section{A definition of spirituality}

Untuk mengembangkan pendekatan terhadap sifat spiritual dari desain, pertama-tama kita harus mendefinisikan apa yang dimaksudkan dengan spiritualitas, khususnya pengalaman spiritual berhadapan dengan lingkungan yang dibangun. Meskipun seseorang dapat beralih ke sejumlah sumber yang hampir tak terbatas dari sastra, seni, dan musik ke teks-teks suci dan risalah filosofis, pada kenyataannya ada sejumlah penyelidikan psikologis ke dalam apa yang merupakan 'pengalaman spiritual' (Maslow 1961; Pahnke dan Richards 1966). Maslow mengidentifikasi 15 karakteristik orang yang termotivasi oleh pengalaman puncak karena terkait dengan transendensi-diri (Maslow 1961):

- Perasaan integrasi, persatuan, keseluruhan, terorganisir.

- Perasaan menyatu dengan dunia; menjadi ego-less.

- Menggunakan semua kapasitas sebaik-baiknya dan sepenuhnya; berfungsi penuh Kesulitan dalam berfungsi (mengalir, 'dalam alur ').

- Merasa bertanggung jawab, aktif, menjadi pusat kegiatan yang menciptakan; menjadi penggerak utama, menentukan nasib sendiri.

- Merasa bebas dari penghalang, penghambatan, peringatan, ketakutan, keraguan, kontrol, pemesanan, dan kritik-diri.

- Spontan, ekspresif, berperilaku tidak bersalah (tidak bersalah, naif, jujur, kekanakkanakan), lebih alami (sederhana, santai, tidak ragu-ragu, tidak terpengaruh) , langsung), lebih terkontrol dan mengalir dengan bebas.

- Keunikan Kreatif, individualitas, istimewa di sini sekarang; bebas dari masa lalu dan masa depan Menjadi "jiwa murni" yang hidup di bawah hukumnya sendiri; lebih sedikit dari dunia dan lebih murni diri.

- Tanpa perjuangan, tidak membutuhkan.

- Ekspresi dan komunikasi menjadi puitis, mistis dan rhapsodic.

- Rasa kelengkapan, keaslian, katarsis.

- Syukur terhadap kekuatan yang lebih tinggi, kerendahan hati, merasa beruntung.

Dengan karakteristik ini, adalah untuk mengembangkan gagasan tentang bagaimana 'pengalaman spiritual' akan terlihat bagi seseorang yang terlibat dalam lingkungan mereka. Pertanyaannya kemudian menjadi: Bagaimana arsitektur dan kota terhubung pada penggunanya dengan cara yang memfasilitasi dan / atau memuji spiritual enlightenment, dengan demikian memenuhi kebutuhan manusia yang lebih tinggi akan transendensi-diri?

\section{A Framework for Exploring Spirituality In The Built Environment}

Mengacu pada karakteristik spiritual enlightenment, kami mengidentifikasi tiga bidang konseptual yang berfungsi untuk memfasilitasi lingkungan yang dibangun dalam mengatasi transendensi-diri, dan memberikan beberapa contoh masing-masing. Kerangka kerja kami berkembang dari ide untuk menghubungkan individu dengan lingkungannya (keberlanjutan), dunia sosial / budayanya (kemanusiaan), dan dirinya yang intim (sensualitas). Diharapkan bahwa dengan menyikapi ketiga bidang yang saling terkait ini arsitektur, perencanaan, dan desain dapat memfasilitasi pengalaman yang lebih bermakna. Kami menggunakan kerangka kerja untuk 
mempertimbangkan bagaimana unsur-unsur lingkungan binaan (mis., Arsitektur, ruang publik, lanskap, program) berkontribusi pada berbagai pengalaman yang merupakan karakteristik keterlibatan spiritual melalui konsep kemanusiaan, sensualitas, dan keberlanjutan.

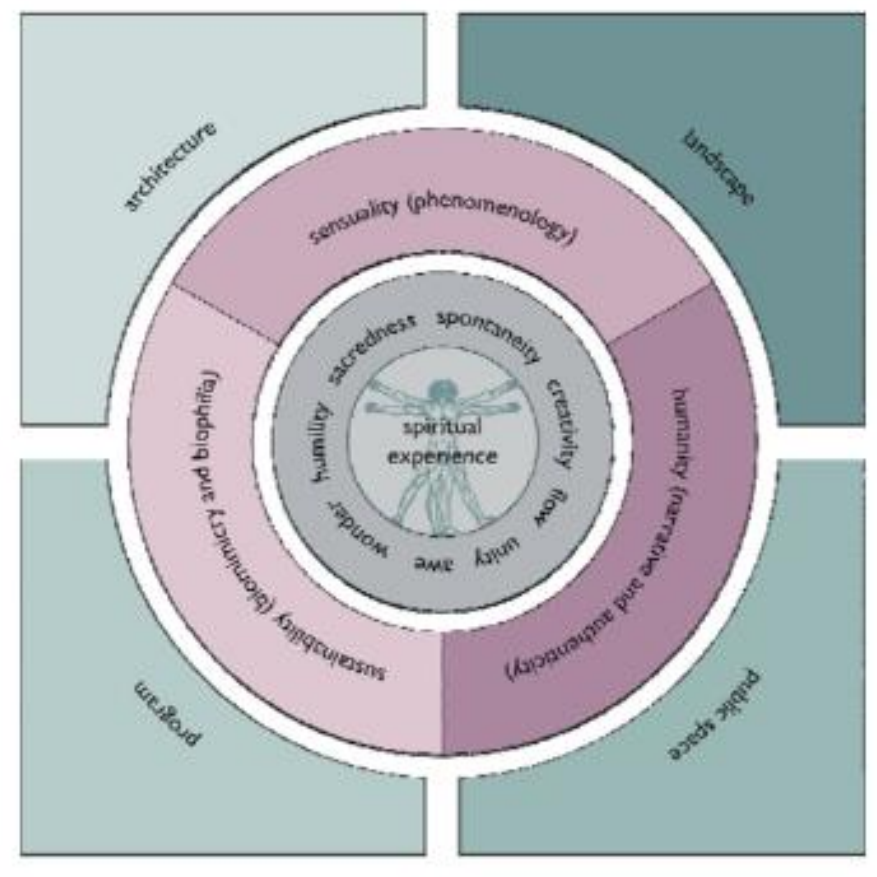

Gambar 1. Kerangka Spiritual

Sumber: Robert Birch, 2013

\section{Sensuality (phenomenology)}

Juhani Pallasmaa dalam bukunya, The Eyes of the Skin, menyinggung konteks historis, antropologis untuk fokus pada mendengar, mencium, menyentuh, mencicipi, dan komunikasi lisan. Putusnya hubungan antara seseorang dan lingkungannya yang dirujuk oleh Pallasmaa ketika ia berbicara tentang "hegemoni mata" (Pallasmaa, 2005) memberikan alasan untuk fokus pada indera dan dampak potensial mereka yang mendalam pada pengalaman spiritual. Ini memperkuat perlunya kerohanian dalam lingkungan kita yang dibangun dan menegaskan kembali keterikatan untuk melibatkan semua indera dalam membangun kembali hubunganhubungan yang terbukti dalam uraian Maslow tentang individu yang berfungsi penuh menggunakan semua kapasitasnya dengan yang terbaik dan sepenuhnya terasa lebih cerdas, lebih perseptif, lebih lucu, lebih kuat, lebih anggun daripada di waktu lain (Maslow, 1961).

Dengan menggunakan keterlibatan sensual penuh dalam desain, lingkungan yang dibangun mendorong fokus pada pola pikir saat ini, "di sini-sekarang", "bebas dari masa lalu dan masa depan yang paling banyak dalam pengalaman" (Maslow, 1961) mengingatkan pada konsep Buddha perhatian. Menciptakan melalui desain, pengalaman sensual yang lebih penuh dan lebih kaya menciptakan kesadaran (sadar atau bawah sadar) tentang lingkungan seseorang dan mengambil langkah-langkah di sepanjang jalan menuju pencerahan (satori) (Watts, 1989). Hubungan antara indera, alam fisik (yang dibangun), dan pengalaman spiritual digaungkan oleh gagasan bahwa "pengalaman manusia ditentukan oleh sifat pikiran dan struktur indra seperti halnya dengan objek-objek eksternal yang kehadirannya pikiran mengungkapkan" (Watts, 1989). Seperti yang disarankan oleh arsitek Peter Zumthor, tidak cukup hanya dengan melibatkan indera dan menggunakan bahan, tekstur, cahaya pada tingkat dasar, tetapi melakukannya dengan cara yang otentik dan jujur bagi pengamat. Perasaan bahwa saya mencoba menanamkan ke dalam materi adalah di luar semua aturan komposisi, dan sifat nyata, bau, dan kualitas akustik hanyalah elemen bahasa yang harus kita gunakan. Sense muncul ketika saya berhasil mengeluarkan makna spesifik dari bahan tertentu di gedung saya, makna yang hanya dapat dirasakan dengan cara ini di gedung yang satu ini (Zumthor, 2010). 


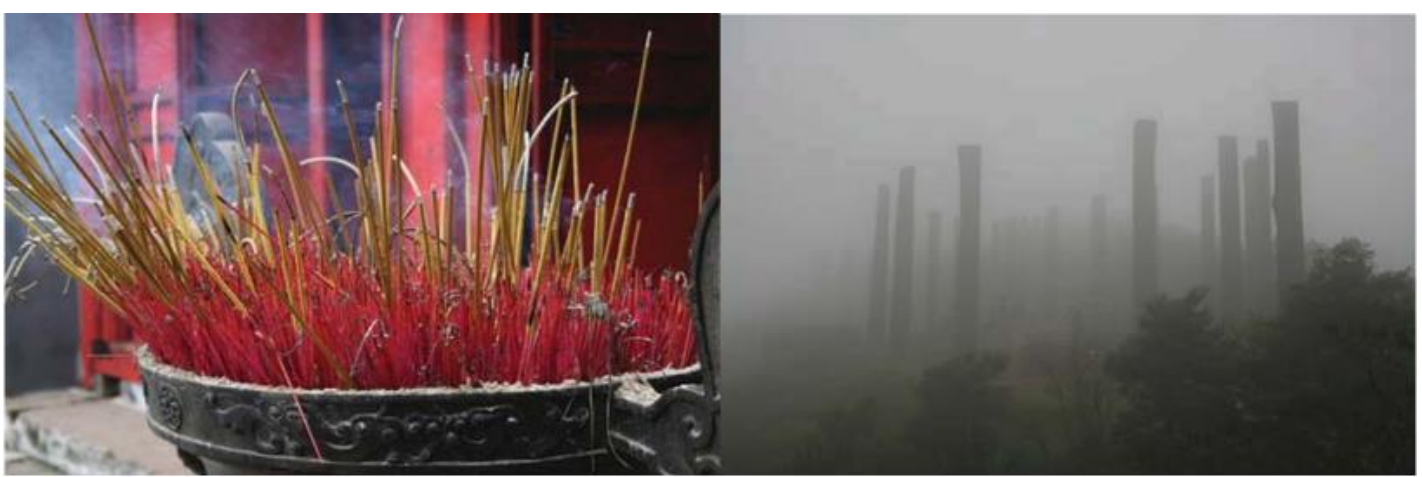

Gambar 2. Figure A + B

Sumber: Robert Birch, 2006

\section{Seven Steps To Soul -A Poetic Journey of Spiritual Awakening}

The First Step Childhood A Life Begins and Soon Forgets

Proses ini sering memakan waktu bertahun-tahun karena sebagian besar dari kita telah belajar dari masa kecil bahwa kita tidak aman untuk sepenuhnya terbuka dan jujur dengan orang lain atau diri kita sendiri. Kita harus belajar untuk tidak menilai reaksi emosional kita atau kita tidak akan merasa cukup aman untuk membawanya ke permukaan.

\section{The Second Step Emotions Healing the Pain}

Seringkali emosi pertama yang akhirnya kita biarkan adalah menyadari dan mengekspresikan yang menyakitkan karena itu adalah kenangan yang kita dorong di awal kehidupan kita. Baru setelah kita dapat menyeimbangkan emosi yang menyakitkan ini dengan emosi kenyamanan dan kebahagiaan, kita dapat menemukan kedamaian. Kedamaian ini, tentu saja, cepat berlalu karena selalu ada katalis baru yang bereaksi. Tetapi, jika kita dapat sadar akan masa lalu kita, kita dapat mengalami setiap momen dengan jelas. Kemudian, kita tidak akan terhalang oleh tantangan kehidupan sehari-hari.

\section{The Third Step Thoughts Learning to Think from Within}

Begitu kita memperoleh kemampuan untuk mengalami emosi kita dan tidak menekannya, atau terperangkap di dalamnya, kita tahu bahwa pikiran kita sering mendorong kita kembali ke negativitas. Maka kita harus membiarkan diri kita mendengarkan diri kita. Ketika kita terjebak, atau tertekan, emosi kita tidak mungkin dapat mendengar pikiran kita. Tetapi, ketika tubuh emosional kita telah tenang, pikiran kita menjadi perhatian kita. Bisakah kita memilih pikiran kita atau pikiran kita yang tidak akan meminta pendapat kita? Hanya ketika kita dapat mendengarkan suara kecil di dalam diri kita, kita dapat membedakan antara pikiran kita dan pikiran yang telah kita pelajari, atau ambil, dari orang lain.

\section{The Fourth Step Relationships Learning to Love Ourselves, Others, and the Planet}

Hubungan adalah hal yang memungkinkan kita untuk belajar tentang cinta dan kekuatan penyembuhan yang dimilikinya. Namun, konflik apa pun yang kita miliki di dalam diri kita akan tercermin pada hubungan di sekitar kita. Jika kita dapat belajar untuk mencintai diri kita sendiri, maka kita dapat memaafkan masa lalu kita dan menciptakan masa depan yang baru. Hanya dengan mencintai diri sendiri, kita dapat membiarkan diri kita cukup percaya untuk mencintai orang lain dengan bebas. Ketika kita benar-benar telah mengizinkan cinta ke dalam hati dan kehidupan kita, kita dapat menyadari bahwa kita masing-masing adalah bagian dari keseluruhan yang lebih besar. Seluruh ini adalah planet kita. Jika kita tidak mencintai planet kita, kita tidak mencintai orang-orang kita karena kita tidak akan menciptakan tempat yang aman bagi mereka untuk hidup. Begitu hati kita dipenuhi dengan cinta, bidang perhatian kita melebar dan tanggung jawab untuk semua kehidupan tumbuh. 


\section{The Fifth Step Creativity Becoming a Vessel of Light}

Ketika cinta telah menyembuhkan masa lalu kita dan menenangkan pikiran dan emosi kita, harapan yang diperbarui sering kali memasuki kesadaran kita. Kreativitas kemudian dapat memasuki kehidupan kita dan kita dapat mulai membebaskan keterbatasan yang diambil selama kehidupan pemisahan - pemisahan dari kesadaran Diri sejati kita. Jika kita dapat membuka hati dan pikiran kita, kita dapat membiarkan cahaya dari awal baru berakar dalam kesadaran kita dan mengisi kita dengan cahaya potensi kreatif kita. Namun, pertama-tama kita harus menghadapi ketakutan kita akan penghakiman, dari orang lain dan dari diri kita sendiri, sehingga kita bisa menjadi cahaya yang selalu menjadi takdir kita. Tetapi untuk melakukan itu kita harus berubah, dan, untuk berubah, kita harus menghadapi yang tidak dikenal.

\section{The Sixth Step Imagination The Joining of Worlds}

Imajinasi adalah bagian kita yang seperti anak kecil. Apakan itu nyata? Mungkinkah imajinasi kita adalah alat yang kuat yang dapat kita gunakan untuk membentuk mimpi kita menjadi masa depan menjadi sekarang? Jika kita dapat mengambil risiko untuk memasuki yang tidak diketahui, kita mungkin menemukan bahwa kita sangat penting sehingga imajinasi kita adalah tali yang mengikat kita dengan Jiwa kita dan karenanya bagi seluruh kehidupan. Melalui imajinasi kita, kita dapat membuat portal antara dunia luar kita dan dunia batin. Jiwa yang kaya di mana segalanya mungkin, jika saja kita bisa membayangkan. Dan, kita adalah penjaga gerbang kita sendiri.

\section{The Seventh Step Freedom Living In Surrender}

Pada awalnya, jiwa mungkin tampak jauh dan terpisah dari kehidupan kita sehari-hari. Tetapi, begitu imajinasi kita membuka jalan dan memulai komunikasi dengan diri kita, kita dapat mulai membawa jiwa kita ke dunia fana kita. Ini membawa energi dan bimbingan Jiwa kita paling baik dicapai jika kita benar-benar bisa menyerah padanya. Jiwa kita adalah bagian dari diri kita yang tidak pernah dilupakan oleh anak batin kita. Bisakah kita percaya sebagai orang dewasa apa yang kita ketahui sebagai anak-anak? Bisakah kita percaya bahwa kita pantas mendapatkan kehadiran Jiwa kita dalam kehidupan kita sehari-hari dan membiarkannya bekerja di dalam dan melalui kita? Bisakah kita menerima bimbingan yang jiwa kita tawarkan secara konstan dan konsisten? Ada banyak pertanyaan yang harus ditanyakan. Untuk menemukan jawaban kita sendiri, kita harus masuk ke dalam $\sim$ ke dalam diri kita sendiri. Jawabannya dapat berubah dengan setiap pencarian. Pencarian inilah yang membentuk hidup kita.

\section{METODE}

\section{Thematic Narrative Architecture}

Pendekatan Thematic Narrative Architecture adalah pendekatan desain dengan menceritakan sebuah proses yang memperhatikan penerapan tema sebagai unsur-unsur pada bangunan. Pendekatan ini didukung oleh sub-metode lainnya yaitu Spatial Gestalts, Experiential Archetypes dan Reference. Teknik pengumpulan informasi dan data tentang masalah yang membutuhkan solusi dan akan dilakukan tahap pengolahan data, berupa :

- Studi Kasus dan Studi Komparasi Studi ini dilakukan dengan mengambil objek - objek yang sejenis yang akan dikomparasi sehingga didapatkan pemahaman dalam perancangan yang dapat membantu proses desain.

- Studi Lapangan Studi ini dilakukan melalui pengamatan terhadap tapak sehingga dapat langsung melihat kelemahan dan keunggulan tapak.

- Studi Literatur Studi untuk mendapatkan masukan berupa standar - standar perancangan, kajian teori maupun contoh - contoh bentukan yang dapat membantu dalam perancangan.

- Analisa Analisa dilakukan pada data - data yang telah ada guna membantu penjelasan dalam suatu kajian. 


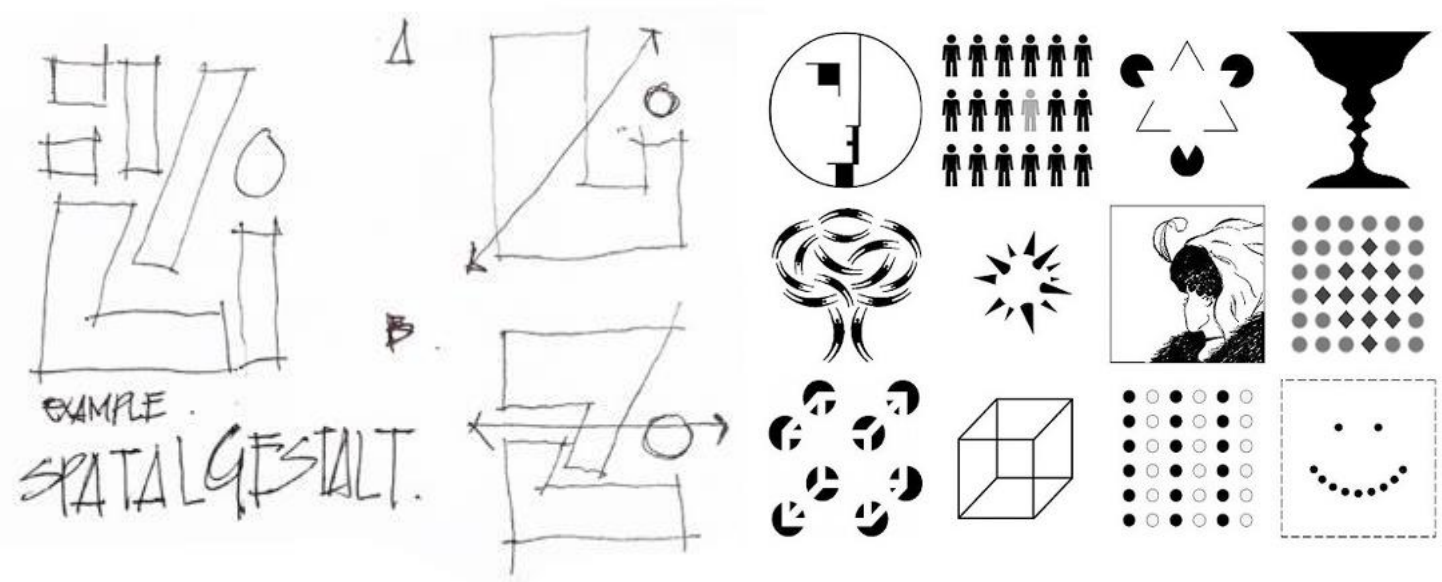

Gambar 3. Spatial Gestalts

Sumber: Penulis, 2019

\section{Spatial Gestalts}

Istilah 'Spatial Gestalt' diambil dari psikologi gestalt. Gestaltist berpendapat bahwa dalam persepsi visual, elemen dikelompokkan ke dalam bentuk atau bentuk kohesif yang memiliki pola atau konfigurasi tertentu. Pola-pola ini lebih diutamakan, dan memiliki kualitas yang tidak melekat pada unsur-unsur individu. Dengan demikian seorang desainer dapat melihat denah lantai tertentu dan bukannya membacanya sebagai sejumlah elemen yang tidak terkait, membacanya sebagai bentuk 'L' atau 'W'.

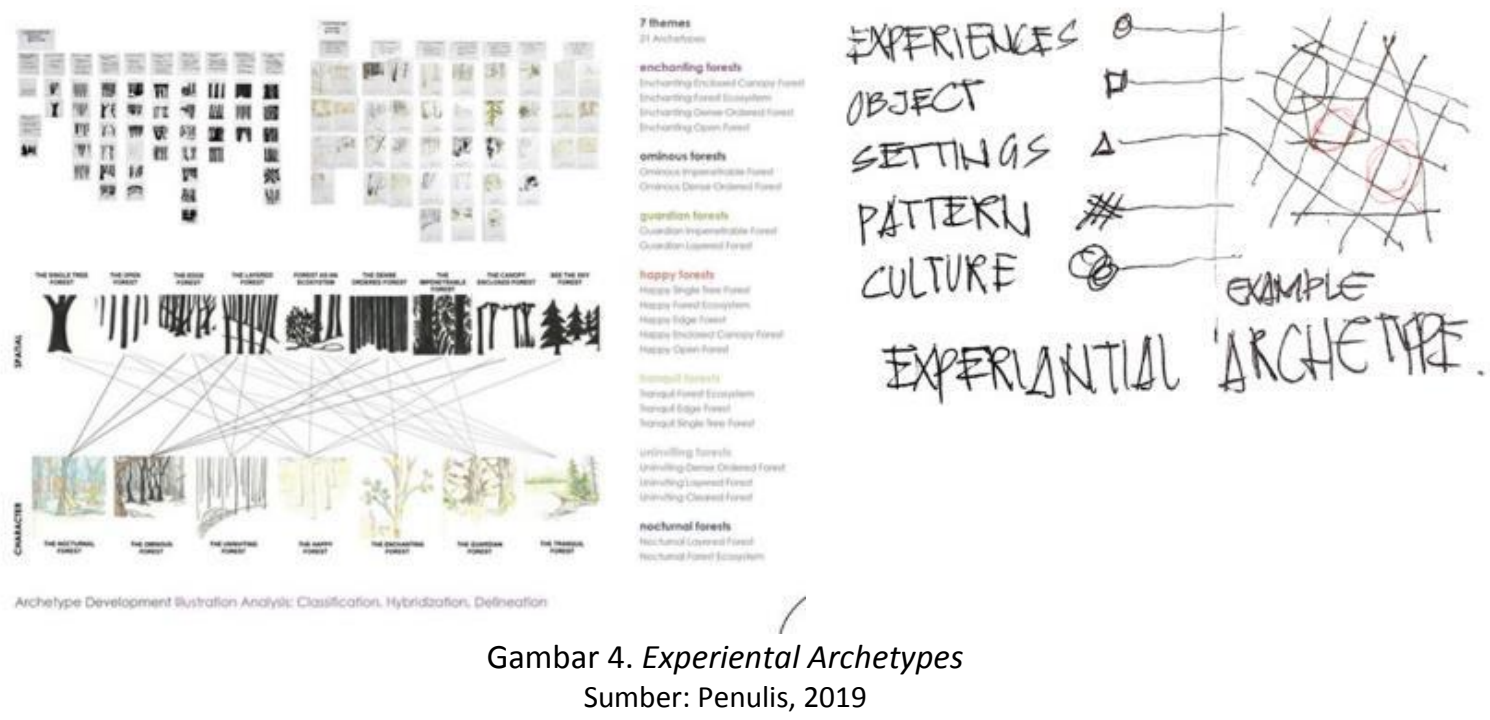

\section{Experiential Archetypes}

Adalah gambar pengalaman, objek, pengaturan, atau hal-hal yang bersifat pribadi bagi desainer. Schbn dan Porter mencatat bahwa arketipe pengalaman berfungsi sebagai 'gambar generatif' untuk premis utama dalam rantai pemikiran desain dan bahwa mereka sering menjadi jelas ketika seorang desainer berada dalam mode 'merasa-jalan', membayangkan seperti apa rasanya berada di dalam atau sekitar ruang tertentu. 


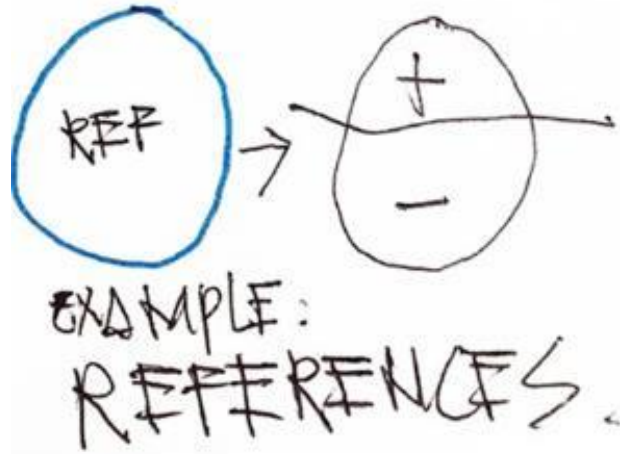

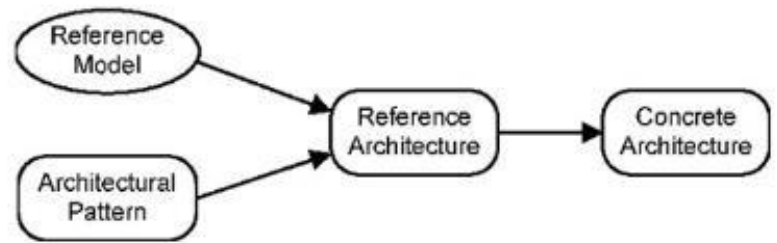

Gambar 5. Reference

Sumber: Penulis, 2019

\section{DISKUSI DAN HASIL}

Konsep perancangan didasarkan pada hasil studi narasi, perilaku, tipologi, warna, ruang spasial , material dan analisis sintesis kawasan - tapak, diawali dengan studi narasi untuk mengetahui proses dimana seseorang dapat mencapai transedensi. Dilanjutkan oleh studi perilaku dan tipologi untuk mengetahui sifat bangunan dan manusia dapat dikelolah, didukung oleh studi warna, ruang spasial dan material sebagai unsur - unsur arsitekturan dalam rancangan ini. Zoning dan sintesa didapat dari hasil analisa kebutuhan dan hubungan antar ruang dan analisis tapak hingga dapat menunjang kebutuhan pengguna secara efisien. Skema desain didapat dari hasil pembentukan massa dan analisis kualitas ruang berdasarkan kebutuhan pengguna.

Hasil desain Urban Retreat Space ini diharapkan membawa pengguna kedalam sebuah perjalanan spiritualitas yang bertujuan sebagai pelepasan emosi bagi pengunjung. Ketujuh program yang di terapkan adalah:

- CHILDHOOD: Program ruang pertama pada proyek ini bertemakan masa kecil, yang akan bertujuan untuk menyadarkan pengguna akan masa lalunya dengan.

- EMOTIONS: Program ruang kedua pada proyek ini bertemakan emosi, yang akan bertujuan untuk menyembuhkan pengguna akan masa lalunya .

- THOUGHTS: Program ruang ketiga pada proyek ini bertemakan pikiran, yang akan bertujuan untuk mengajarkan pengguna untuk belajar untuk berpikir dan dalam dirinya.

- RELATIONSHIPS: Program ruang keempat pada proyek ini bertemakan hubungan, yang akan bertujuan untuk mencintai diri sendiri, orang lain dan sekitarnya.

- CREATIVITY: Program ruang kelima pada proyek ini bertemakan kreativitas, yang akan bertujuan untuk memperbaharui diri dan menghilangkan limitasi pada pengguna.

- IMAGINATION: Program ruang keenam pada proyek ini bertemakan imajinasi, yang akan bertujuan untuk membuka pikiran dan jiwa pengguna pada dunia dengan kemungkinan yang tidak terbatas.

- FREEDOM: Program ruang terakhir pada proyek ini bertemakan kebebasan, yang akan bertujuan untuk melepaskan pikiran dan jiwa pengguna. 


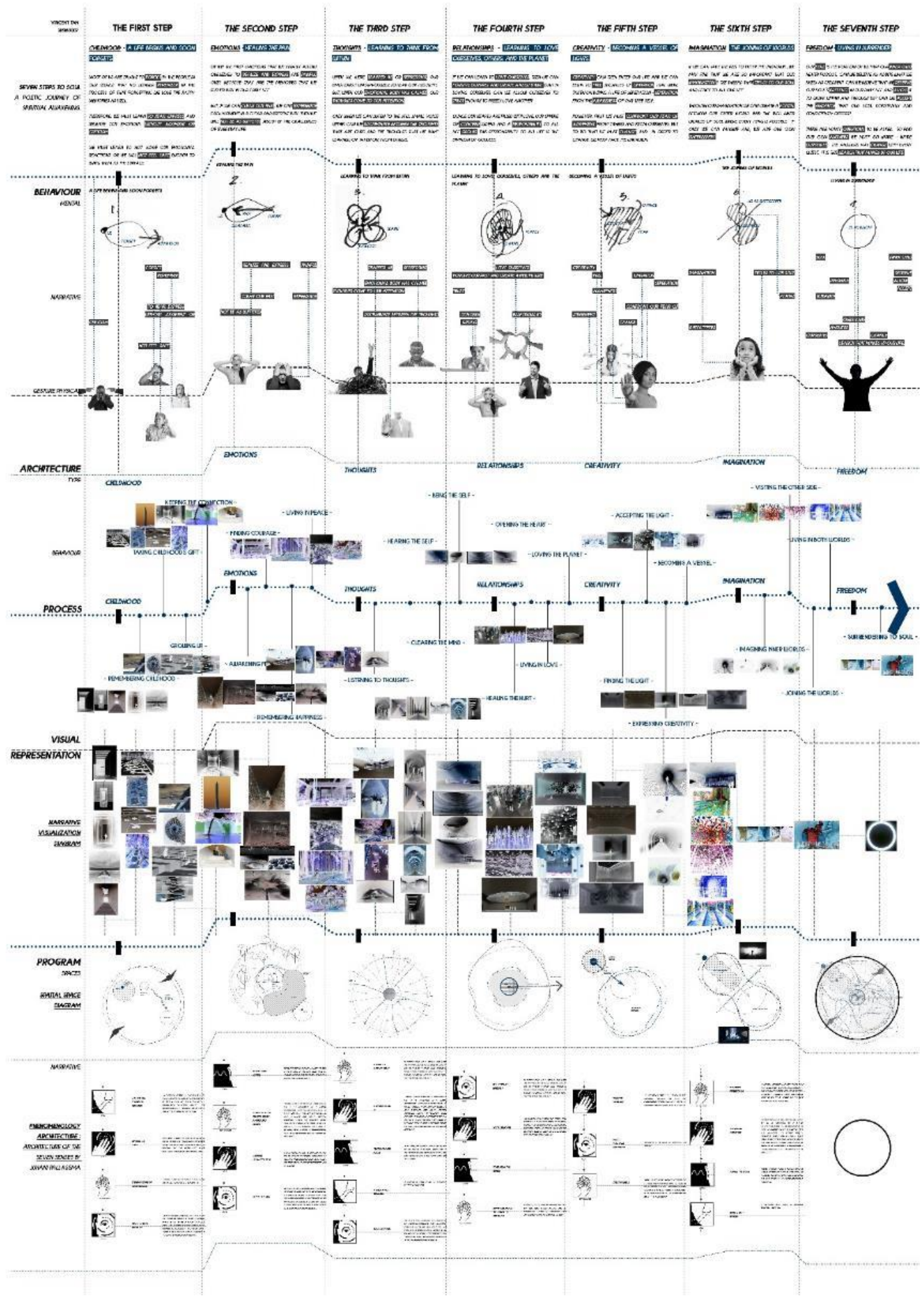

Gambar 6. Diagram Matrix Perilaku, Tipe dan Arsitektur

Sumber: Penulis, 2019 


\section{KESIMPULAN DAN SARAN}

Proyek rancangan "Urban Retreat Space" membawa pengguna kedalam sebuah pengalaman spiritual dengan pendekatan narrative story telling. Dengan menggunakan studi behaviour dan type sebagai dasar utama rancangan proposal ini. Dengan selesainya Tugas Akhir ini, penulis dapat menarik kesimpulan antara lain :

- Retreat space atau tempat retret diawali dari perkembangan jaman telah mengalami perubahan dari yang bersifat medikal ( kaku, formal, terukur) kearah spiritual (holistik, transeden, relaksasi) .

- Dalam merancang tempat retret unsur penghijauan (biophillic) sangat penting dalam melepaskan emosi pengguna.

- Aspek arsitektural seperti material, warna dan besar ruang - pengalaman ruang dapat mempengaruhi pengguna dengan pendekatan alam dapat memberikan efek relaksasi dan penyembuhan bagi pengguna.

- Dalam perencanaan elemen struktur antara lain, balok, kolom dan plat memberikan unsur tektonika bangunan yang dapat membantu dalam proses pengalaman spiritual.

- Dengan menggunakan studi behaviour dan type sebagai dasar utama perancangan desain ini, emosi dan perilaku pengunjung terhubung dengan tema desain rancangan studi retret ini.

Proposal ini mengkaji buku Seven Steps To Soul - a Poetic Journey to Spiritual Awakening karya Susan Caroll PH D sebagai landasan teoritis yang di terjemahkan ke dalam arsitektur tematik.

\section{REFERENSI}

Alexander, C. (1977). A Pattern Language. Oxford University Press.

Bagnall, R. S. (2004). Egypt from Alexander to the Early Christians: An Archaeological and Historical Guide. Getty Publications.

Browning, W., Ryan, C., \& Clancy, J. (2014). 14 Pattern Of Biophilic Design. Terrapin.

Calvino, I. (1974). Invisible Cities. Giulio Einaudi.

Dehaene, M., \& Cauter, L. D. (1994). Heterotopia and the City. Routledge.

Ellison, C. W., \& Maynard, E. S. (1992). Healing for the City. Zondervan Publishing House.

Gabra, G. (2002). Coptic Monasteries : Egypt's Monastic Art and Architecture. The American University in Cairo Press.

Hayllar, Griffin, Edwards, \& Deborah. (2008). City Spaces - Tourist Places. ButterworthHeinemann.

Kementerian Pariwisata Indonesia. (2016). Neraca Satelit Pariwisata Nasional (Nesparnas). Kementerian Pariwisata Indonesia.

Kementerian Pariwisata Indonesia. (2016). Statistik Profil Wisatawan Nusantara Tahun 2016. Kementerian Pariwisata Indonesia.

Knieling, J. (2014). Metropolitan Regions : Definitions, Typologies and Recommendations for development cooperation. GIZ.

Koolhaas, R. (1994). Delirious Newyork. The Monacelli Press, Inc.

Koolhaas, R. (2007). Mutation. Actar.

Koolhaas, R., \& Boom, I. (2014). Elements of Architecture. Marsilio.

Lee, C. C. (2011). Projective Cities: Typological Formations, Renewable Building Types and the City. Architectural Association and the Authors.

Lee, C. C. (2012). The Fourth Typology, Dominant Type and the Idea of the City. TU Delft. Lerner, J. (2014). Urban Accupuncture. Island Press.

Lynch, K. (1960). The Image of the City. MIT Press.

Maciocco, G., \& Serreli, S. (2009). Enhancing the City, New Perspective for Tourism and Leisure. Springer.

Moneo, R. (1978). On Typology, Oppositions. MIT Press. 
Morosetti, L. (2015). The contemporary monastery : Application and adaptation of the monastic typology to contemporary collective housing. TU Delft.

Rossi, A. (1982). The Architecture of the City. MIT Press.

Rowe, C., \& Koetter, F. (1978). Collgae City. MIT Press.

Rudolf, S. (2008). A Design Manual : Sacred Building . Birkhauser.

Santoso, J. (2011). The Fifth Layer of Jakarta. Tarumanagara University.

Santoso, J. (2015). transformasi urban metropolitan jakarta, adaptasi dan pengembagan.

Tarumanagara University.

Schulz, N. (1979). Genius Loci. Rizolli.

Signh, L. K. (2008). Fundamental of Tourism And Travel. ISHA.

Sorkin, M. (1992). Variation on a Theme Park. Hill and Wang.

Specht, J. (2014). Architectural Tourism, Building for Urban Travel Destination. Springer Gabler.

Strappa, G., Amato, A. R., \& Camporeale, A. (2015). City as Organism. U+D Edition.

Sugiharto, B. (2008). Humanisme dan Humaniora. Matahari.

Sutanto, A. (2018). Architourism = Program + Bentuk. Studio Perancangan Arsitektur VIII - 26.

The World Tourism Organization. (2017). UNWTO Tourism Highlight. World Tourism Organization.

Thiry, P., Bennett, R. M., \& Kamphoefner, H. L. (1954). Churches \& Temples. Reinhold Pub. Corporation.

Tjahjono, G. (2000). Metode Perancangan, , Suatu pengantar untuk arsitek dan perancang. Universitas Indonesia.

Zamfir, A., \& Corbos, R.-A. (2015). Towards Sustainable Tourism Development in Urban Areas:. MDPI. 